\title{
SUSTAINABLE TOURISM FACILITIES AND THEIR IMPACT ON THE KUYAVIAN-POMERANIAN VOIVODESHIP TOURISM COMPETITIVENESS
}

\author{
Marek JÓŹWIAK \\ UTP University of Science and Technology in Bydgoszcz, Faculty of Management, Bydgoszcz, Poland; \\ marek.jozwiak@utp.edu.pl, ORCID: 0000-0001-9291-7518
}

Purpose: Tourism is presently one of the fastest-growing branches of the economy. It is therefore crucial to maintain balance between three aspects, i.e. the social, the economic and the environmental, which is possible owing to one of the most important nexuses of sustainable development, namely sustainable tourism. This article thus attempts to define the concept of sustainable development and sustainable tourism. Empirically, the article aims to identify instances of areas and facilities functioning as elements of sustainable tourism as well as to key out their impact on the growing number of tourists, and consequently on the increasing tourist competitiveness of the Kuyavian-Pomeranian Voivodeship.

Design/methodology/approach: This article analyzes the latest scientific literature in terms of sustainable development and sustainable tourism. Reports from Statistics Poland (GUS) were analyzed in the study.

Findings: As a result of the conducted analysis an increase in the number of the tourists visiting the two largest cities of the Kuyavian-Pomeranian voivodeship, i.e. Bydgoszcz and Torun may by observed. The number of eateries operating in the Kuyavian-Pomeranian voivodeship increased each year, compared to the other two voivodships under examination. This has had significant impact on the voivodeship's increased tourist competitiveness. The KuyavianPomeranian voivodeship additionally offers a large number of tourist routes.

Originality/value: Results of the conducted analysis enrich the literature concerning on sustainable development and sustainable tourism. In addition, they serve as recommendation for conducting further quantitative research in this field.

Keywords: Agenda 21, Kuyavian-Pomeranian Voivodeship, sustainable development, sustainable tourism.

Category of the paper: Literature review. 


\section{Introduction}

Competition is one of the phenomena observed in all areas of human activity, hence it is of interest to many specialists. One of the most important topics addressed in management or economic sciences is the competition in economy.

One of the effects of economic development is its negative impact on the environment. For many years, social movements, whose main task is to reduce the negative impact on the environment and help improve the life of local communities, have been advocated.

Many disciplines, including natural, social and economic sciences, have undertaken research on the concept of sustainable development. In regional and local development strategies, tourism has been playing an increasing role in terms of positioning, which is why it is so important to create more tourist destinations in the spirit of sustainable tourism.

Sustainable tourism is a discipline devising branded products of a region, the quality of which very often primarily depends on the conditions resulting from the region's natural predispositions.

This article attempts to define the concept of sustainable development and sustainable tourism. Empirically, it aims to identify instances of areas and facilities functioning as elements of sustainable tourism as well as to key out their impact on the growing number of tourists, and consequently on the increasing tourism competitiveness of the Kuyavian-Pomeranian Voivodeship.

The article was written based on the results of own observation and the analysis of the subject matter literature. To accomplish the goal assumed, analysis was carried out with reference to the number of the tourist routes, the number of the tourists staying at accommodation facilities, the number of eateries as well as the number of the tourists visiting the largest cities of the Kuyavian-Pomeranian voivodeship and two neighboring voivodeships. Additionally, the sustainable tourism facilities operating in the Kuyavian-Pomeranian voivodeship have been presented as well. The results of the analysis supplement the literature on sustainable development and sustainable tourism. One additional value resulting from the study entails development of resources for further quantitative research in this area. 


\section{The concept of sustainable development}

The concept of sustainable tourism is a relatively raw notion, existing in both Polish and world literature. To elucidate on what sustainable tourism is, however, one should go back to the very beginning.

The concept of sustainable tourism arose from the implementation of the sustainable development principles functioning in various economic zones. Humans and their activity have significant, destructive impact on the natural environment. That is why initiation of changes that will have positive impact on the ecosystem, but will also affect human activity, was so important. The concept of sustainable development was the answer to that (Zawistowska, 2014; Płachciak, 2011).

Sustainable development was first mentioned in the 1980 World Conservation Strategy report, which emerged after years of intensive development of the environmental thought into its present shape. One crucial event, deemed as the beginning of sustainable development, was the speech of the UN Secretary General U Thant in 1968, followed by publication of the "Man and His Environment" report in 1969. In addition to the above-mentioned report, it is also worth mentioning "The Limits to Growth" published by the Club of Rome in 1972, which also attempted to determine the human impact on the environment (Lemkowska, 2020; Meadows et al., 1972).

Although the report publication is considered have initiated the idea, it was only after many years that an attempt was made to develop the first definitions of sustainable development, i.e. in 1987, when the World Commission on Environment and Development published the "Our Common" report prepared by the World Commission on Environment and Development, often also referred to as the 'Brundtland Commission' (UN, 1987; Lemkowska, 2020).

The report produced by the Commission, introduced a definition of sustainable development, which was presented in both an economic and a political context. According to the report, sustainable development is such development, which meets the needs of the present generation, without limiting the future generation' prospects for satisfying these needs. The definition developed for the purpose of the report had functioned in the world of science for many years and had its share in the formulation of legal and political acts or development strategies (Rokicka, Woźniak, 2016; Stanny, Czarnecki, 2011).

Over the years, many definitions have been formulated, which bring us closer to the essence of sustainable development. Table 1 presents various authors' definitions of sustainable development. 
Table 1.

Different definitions of sustainable development

\begin{tabular}{|c|c|c|}
\hline No. & Author & Definition \\
\hline 1. & $\begin{array}{l}\text { Sztumski W. Idea zrównoważonego } \\
\text { rozwoju a możliwości jej } \\
\text { urzeczywistnienia, PROBLEMY } \\
\text { EKOROZWOJU 2006, Vol. 1, } \\
\text { No. 2, pp. 73-76. }\end{array}$ & $\begin{array}{l}\text { A process of country, city, business, community etc. } \\
\text { development, which connects the needs of the present } \\
\text { generation unconditionally with the ability to meet the needs } \\
\text { of future generations, and the needs of certain people with the } \\
\text { needs of others. }\end{array}$ \\
\hline 2. & $\begin{array}{l}\text { Turner R.K. 1988, Pluralism in } \\
\text { an environmental economics: } \\
\text { a survey of the sustainable economic } \\
\text { development debate. Journal of } \\
\text { Agricultural Economics, Vol. } 39 . \\
\end{array}$ & $\begin{array}{l}\text { Sustainable development necessitates maximization } \\
\text { of economic growth net benefits, in order to maintain over-time } \\
\text { access to natural resource services and quality. }\end{array}$ \\
\hline 3. & $\begin{array}{l}\text { Kozłowski S. 1998, Ekologiczne } \\
\text { problemy przyszłości świata } \\
\text { i Polski. Komitet Prognoz „Polska } \\
\text { w XXI wieku” przy Prezydium } \\
\text { PAN, Warsaw. }\end{array}$ & $\begin{array}{l}\text { Such manner (model) of a specific area's socio-economic } \\
\text { development, whose assumptions result from the natural } \\
\text { conditions, do not violate the ecological balance and guarantee } \\
\text { the survival of not only the present but also the future } \\
\text { generations. }\end{array}$ \\
\hline 4. & $\begin{array}{l}\text { Runowski H. 2002, Rozwój } \\
\text { zrównoważony rolnictwa } \\
\text { i gospodarstw rolniczych. Wieś } \\
\text { i rolnictwo - perspektywy rozwoju. } \\
\text { IERiGŻ, IRWiR PAN, SGH, } \\
\text { Warsaw. }\end{array}$ & $\begin{array}{l}\text { The strive to achieve balance between different goals of socio- } \\
\text { economic development, without which it is difficult to maintain } \\
\text { system longevity. The concept of lasting development } \\
\text { somewhat determines the main objective of system stability and } \\
\text { continuity. The term sustainable development, in turn, indicates } \\
\text { the way of proceeding in order to achieve the goal of } \\
\text { permanence. }\end{array}$ \\
\hline 5. & $\begin{array}{l}\text { Kassenberg A. 2007, } \\
\text { Zrównoważony rozwój a koncepcja } \\
\text { przestrzennego zagospodarowania } \\
\text { kraju, [w:] Rozwój, region, } \\
\text { przestrzeń, (red.) G. Gorzelak, } \\
\text { A. Tucholska, MRR, EUROREG, } \\
\text { Warsaw. }\end{array}$ & $\begin{array}{l}\text { The essence of sustainable development entails the pursuit } \\
\text { for equal approach to the social, economic and environmental } \\
\text { rationales in each decision making, where applicable. } \\
\text { This, however, does not mean a mere compromise. It is more of } \\
\text { an integral plane rather than a configuration of three separate } \\
\text { components. }\end{array}$ \\
\hline
\end{tabular}

Source: own elaboration based on subject matter literature.

Definitions of sustainable development can also be found in legal documents, for instance in the Act of April 27, 2001, Environmental Protection Law. Sustainable development is understood as "such socio-economic development, in which political, economic and social activity integration occurs, maintaining natural balance and durability of basic natural processes, in order to guarantee the possibility of meeting the basic needs of individual communities or citizens, with regard to both the present and the future generations" (Journal of Laws 2018, item 799).

Although various definitions of sustainable development exists in the literature, they all exhibit common elements. Sustainable development is often viewed as the search for a perfect solution, as to combine such three important aspects as: the natural environment, the economy and the society. Sustainable development has been applied in many areas of economic life. Increasingly often it has been observed in tourism as well. 


\section{Sustainable tourism}

Tourism presently is one of the fastest growing branches of the economy. The report published by the World Travel \& Tourism Council indicates that in 2019, the tourism industry accounted for $10.3 \%$ of the global GDP, which translated into US dollars 8.9 trillion. The rapid development of tourism had significant impact not only on the life of entire communities, but above all on the natural environment. This is one of the reasons why the concept, the main objective of which was to reduce the negative impact, was developed (WTTC, 2020; Widawska-Stanisz, Majewska, 2019).

The notion of sustainable tourism was first introduced in 1996 by the World Tourism Organization (UNWTO). The official UNWTO definition referred to it as the tourism "leading to management of all resources in such a way that economic, social and aesthetic needs can be fulfilled while maintaining cultural integrity, essential ecological processes, biological diversity, and life support systems" (Agenda 21, 1994; Bajdor, Grabara, 2012).

Many definitions describing this concept can be found in the literature on sustainable tourism. Nevertheless, the definitions developed by two international organizations are most frequently cited. Table 2 presents these definitions of sustainable tourism.

Table 2.

The concept of "sustainable tourism"

\begin{tabular}{|l|l|l|}
\hline No. & \multicolumn{1}{|c|}{ Document } & \multicolumn{1}{c|}{ Definition } \\
\hline 1. & $\begin{array}{l}\text { World Tourism } \\
\text { Organization }\end{array}$ & $\begin{array}{l}\text { Sustainable tourism development meets the needs of present tourists and host regions } \\
\text { while protecting and enhancing opportunity for the future. It is envisaged as leading } \\
\text { to management of all resources in such a way that economic, social, and aesthetic } \\
\text { needs can be fulfilled while maintaining cultural integrity, essential ecological } \\
\text { processes, biological diversity, and life. }\end{array}$ \\
\hline 2. & $\begin{array}{l}\text { World Trade } \\
\text { Organization }\end{array}$ & $\begin{array}{l}\text { Sustainable tourism satisfies present needs of the tourists and destinations by } \\
\text { protecting and increasing opportunities for the future. }\end{array}$ \\
\hline
\end{tabular}

Source: own elaboration based on: Agenda 21 for the Travel and Tourism Industry.

Sustainable tourism has been included in the New Urban Agenda as one of the sectors that can have significant impact on urban economy and generation of new, high-quality jobs. The remarkable development of sustainable tourism may be related to the activities that are not only meant to stimulate the tourist traffic, but primarily have positive impact on the economic situation and the life of local residents, and above all, are intended to help avoid the negative effects of urban space overtourism, enabling sustainable development of tourism initiatives that are beneficial for both the tourists and the residents (Komorowski, Hołderna-Mielcarek, 2019).

It should be noted that, in the era of the growing popularity of tourism and the increasing demand for this type of services, sustainable tourism is meant to ensure development of environmentally friendly tourism and provide sustainable socio-economic development. Sustainable tourism is therefore intended to make optimal use of the natural resources that constitute its key developmental element. What is more, it involves respect for the socio- 
cultural values, the cultural heritage and the traditional values that may contribute to intercultural development. Long-term socio-economic benefits should also be ensured to all parties involved in the development of tourism (Niezgoda, 2004; Tnguay et al., 2013).

The beginning of sustainable tourism can be traced back to the First United Nations Conference of 1972, where had been brought to the urgency for integrating fast economic development with environmental protection. It was during the Second United Nations Conference held in 1992, however, when solutions that had actual impact on environmental protection were adopted. The conference ended with adoption of very important arrangements regarding tourism, i.e. Agenda 21 (Gawor, 2006; Burchard-Dziubińska, 2014).

The Second United Nations Conference, held in Rio de Janeiro, was one of the largest and most significant conferences devoted to contemporary environmental issues and sustainable development. The so-called Earth Summit, where over ten thousand delegates from 176 countries met, was one of its highlights. These countries were represented by the most important persons holding the highest positions of state power (Burchard-Dziubińska, 2014).

The conference was concluded with a document called "Agenda 21 - an action plan for global sustainable development for the $21^{\text {st }}$ century", containing a set of 2500 recommendations for states, organizations and societies. In the subject matter literature, as well as in everyday life, the document functions under a shorter name, i.e. "Agenda 21". It is an important document, whose main task is to promote the idea of sustainable development and environmental protection. It constitutes the basis for development and implementation of regional and national sustainable development strategies (Rydz-Żbikowska, 2012).

Agenda 21 aims to ensure development in a sustainable manner, through a system of incentives and penalties stimulating economic behavior. In addition to its main objective, Agenda 21 also contained other secondary targets, which, inter alia, include (Ferreira, 2017):

- eradication of poverty,

- sustainable exploitation of such global and regional resources as the atmosphere, the oceans and the seas, fresh water reserves as well as marine life.

Agenda 21 consists of four parts. Each of these parts pertains to separate but related areas of development (Agenda 21, 1992):

- Section I - discusses economic and social issues, covering, inter alia: international cooperation, aimed at acceleration of sustainable development and implementation of appropriate internal policies in developing countries; the fight against poverty; the changes in the consumption pattern; promotion of lasting, sustainable development of human settlements, etc.

- Section II - discusses the problems related to natural resource protection and management, in eco-development terms. The topics addressed include: protection of the atmosphere; the measures to prevent deforestation; management of vulnerable (unstable) ecosystems; prevention of desertification and droughts; protection of biodiversity; protection of inland water resource quality and exploitation; an integrated 
approach to the problem of inland water resource development and management; environmentally safe hazardous waste management; prevention of illegal international hazardous waste trade; safe and environmentally sound handling of radioactive waste, etc.

- Section III - covers the issues of reinforcing the role of the main social groups and organizations, addressing the following in detail: the role of women, children and the youth in sustainable development; reinforcement of the non-governmental organizations' role, who are partners in sustainable development activity; reinforcement of the role workers and trade unions play in lasting, sustainable development; reinforcement of the scientific and technical communities' role in the provision of foundations and conditions for sustainable development; expansion of the farmers' role in the process of sustainable development, etc.

- Section IV - the last part of the Agenda discusses implementation of specific tasks, addressing the following in detail: the funding measures and mechanisms; the role of science in sustainable development; promotion of teaching; the shaping of social awareness, including sustainable development and environmental protection trainings; implementation possibilities in terms of state mechanisms and international cooperation; international legal mechanisms and instruments; information for decision making purposes, etc.

Agenda 21 presents one of the most important policy assumptions, which aims to strike a possible balance between such elements as the world's population and the ability to continue the evolution of life. Nonetheless, one very important Agenda 21 aspect entails emphasis on the fact that the changes occurring in the natural environment are conditioned by such factors as consumption, technology or the changes in the demographic structure. The document provides guidelines for reduction of land, air and water degradation, forest preservation, as well as conservation of the diversity of the species living on Earth. Agenda 21 covers many areas of economic life. One of these areas is tourism, which has had an increasing impact on the natural environment. Development of the concept of sustainable tourism is therefore a significant occurrence, not only meant to call attention to the protection of the natural environment, but also to accentuate the care for the local communities.

\section{The Kuyavian-Pomeranian and the Warmian-Masurian Voivodeship tourism competitiveness}

The Kuyavian-Pomeranian voivodeship is located in the north-central part of Poland. In 2019, the voivodship had 2072373 inhabitants. The Warmian-Masurian voivodeship is located in the north-eastern part of the country. The number of inhabitants in 2019 was 
1422700 , whereas the Łódź voivodeship is located in the central part of the country and the number of inhabitants in 2019 was 2455000 (GUS, 2020).

The unique values of the Kuyavian-Pomeranian, the Warmian-Masurian and Lódź voivodships have contributed to the significant development of tourism in the region. The tourism values include, among others, the natural environment and the landscape, the large number of water bodies and the cultural heritage. Owing to these values, among other things, the voivodship was able to develop sustainable tourism.

Over the last decade, the Kuyavian-Pomeranian, the Warmian-Masurian and Łódź voivodships have become more attractive touristically. This has been confirmed, inter alia, by the increase in the number of the tourists visiting the region. Table 3 . shows the number of the overnight stays recorded in the tourist accommodation establishments in these voivodships. A significant increase in the number of the tourists who decided to stay at the accommodation facilities can be observed. The highest increase in the Kuyavian-Pomeranian voivodeship was recorded in 2016, amounting to $12.87 \%$, compared to 2015. In the Warmian-Masurian voivodeship, similarly to the Kuyavian-Pomeranian voivodeship, the highest increase was recorded in 2016, amounting to $14.62 \%$, compared to 2015, whereas in the Łódź voivodship, the highest increase was observed in 2017. The data presented indicates a significant difference between domestic and foreign tourist data. In the Warmian-Masurian and the Łódź voivodships, the number of foreign tourists increased each year, as opposed to the Kuyavian-Pomeranian voivodship. In 2018, a decrease in the number of foreign tourists staying at accommodation facilities can be observed in the Kuyavian-Pomeranian and the Warmian-Masurian voivodships $(-3.40 \%$ and $-3.16 \%$, respectively, compared to 2017$)$. Detailed information on the percentage change in the number of the tourists staying at the accommodation facilities is presented in Table 4.

\section{Table 3.}

The Kuyavian-Pomeranian voivodeship versus selected voivodeships in terms of the accommodation base use

\begin{tabular}{|c|c|c|c|c|c|c|}
\hline \multirow{2}{*}{ Year } & \multicolumn{6}{|c|}{ Number of tourists staying at accommodation facilities: } \\
\cline { 2 - 7 } & \multicolumn{2}{|c|}{$\begin{array}{c}\text { Kuyavian-Pomeranian } \\
\text { voivodeship }\end{array}$} & \multicolumn{2}{c|}{$\begin{array}{c}\text { Warmian-Masurian } \\
\text { voivodeship }\end{array}$} & \multicolumn{2}{c|}{ Lódź voivodeship } \\
\cline { 2 - 7 } & $\begin{array}{c}\text { Domestic } \\
\text { tourists }\end{array}$ & $\begin{array}{c}\text { Foreign } \\
\text { tourists }\end{array}$ & $\begin{array}{c}\text { Domestic } \\
\text { tourists }\end{array}$ & $\begin{array}{c}\text { Foreign } \\
\text { tourists }\end{array}$ & $\begin{array}{c}\text { Domestic } \\
\text { tourists }\end{array}$ & $\begin{array}{c}\text { Foreign } \\
\text { tourists }\end{array}$ \\
\hline 2015 & 950400 & 105100 & 977438 & 157602 & 1081300 & 199700 \\
\hline 2016 & 1072700 & 120500 & 1120365 & 160199 & 1042800 & 167900 \\
\hline 2017 & 1179300 & 120700 & 1094983 & 167641 & 1118700 & 189600 \\
\hline 2018 & 1183400 & 116600 & 1146228 & 162345 & 1156400 & 194900 \\
\hline 2019 & 1278700 & 121300 & 1212729 & 164721 & 1230700 & 192900 \\
\hline
\end{tabular}

Source: own elaboration based on: Turystyka w województwie kujawsko-pomorskim latach 2015-2019; Informacja o ruchu turystycznym w województwie warmińsko-mazurskim w 2019 roku; Turystyka w województwie łódzkim w latach 2015-2019. 
Table 4.

Percentage change in the number of the tourists staying at accommodation facilities in selected voivodeships

\begin{tabular}{|c|c|c|c|c|c|c|}
\hline \multirow{2}{*}{ Year } & \multicolumn{2}{|c|}{\begin{tabular}{c} 
Percentage variation in the number of the tourists staying at accommodation facilities: \\
\cline { 2 - 7 }
\end{tabular}} & $\begin{array}{c}\text { Kuyavian-Pomeranian } \\
\text { voivodeship }\end{array}$ & \multicolumn{2}{|c|}{$\begin{array}{c}\text { Warmian-Masurian } \\
\text { voivodeship }\end{array}$} & \multicolumn{2}{c|}{ Lódź voivodeship } \\
\cline { 2 - 7 } & $\begin{array}{c}\text { Domestic } \\
\text { tourists }\end{array}$ & $\begin{array}{c}\text { Foreign } \\
\text { tourists }\end{array}$ & $\begin{array}{c}\text { Domestic } \\
\text { tourists }\end{array}$ & $\begin{array}{c}\text { Foreign } \\
\text { tourists }\end{array}$ & $\begin{array}{c}\text { Domestic } \\
\text { tourists }\end{array}$ & $\begin{array}{c}\text { Foreign } \\
\text { tourists }\end{array}$ \\
\hline 2015 & - & - & - & - & - & - \\
\hline 2016 & $12.87 \%$ & $14.65 \%$ & $14.62 \%$ & $1.65 \%$ & $-3.56 \%$ & $-15.92 \%$ \\
\hline 2017 & $9.94 \%$ & $0.17 \%$ & $-2.27 \%$ & $4.65 \%$ & $7.28 \%$ & $12.92 \%$ \\
\hline 2018 & $0.35 \%$ & $-3.40 \%$ & $4.68 \%$ & $-3.16 \%$ & $3.37 \%$ & $2.80 \%$ \\
\hline 2019 & $8.05 \%$ & $4.03 \%$ & $5.80 \%$ & $1.46 \%$ & $6.43 \%$ & $-1.03 \%$ \\
\hline
\end{tabular}

Source: own calculation.

Regions that are touristically developed can be identified in the Kuyavian-Pomeranian voivodeship. These regions' attractiveness results, inter alia, from: the communication infrastructure and the network of canoeing, hiking and cycling routes, as well as the culinary and hotel infrastructure. One important aspect affecting the region's attractiveness is the quality of the services provided. Its attractiveness have been additionally conditioned by various tourist-oriented offers, most important of which are canoeing trips, tour events, fairs, concerts and festivals, all organized with respect for environmental protection and the region's cultural heritage.

The above-mentioned tourist regions of the Kuyavian-Pomeranian voivodeship include (Guide-Tourism, 2020):

- the Tuchola Forest region,

- the Włocławek region, including the Włocławek Reservoir and the GostyninWłocławek Landscape Park,

- the Brodnica region, with its Lansdcape Parks: Brodnica Landscape Park and the Górzno-Lidzbark Landscape Park,

- the Koronowo region with the Brda River and the Koronowski Resevoir,

- the Kruszwica-Żnin region with the Lake Gopło,

- the Toruń region with cities of Toruń, Chełmża and Ciechocinek,

- the Lower Vistula valley with cities of Bydgoszcz, Chełmno and the Complex of Landscape Parks - Chełmno and Vistula Landscpae Parks.

All of the above-listed tourist sites are characterized by ideal conditions for development of sustainable tourism, which has contributed to the significant increase in the region's competitiveness in terms of tourism development and the influx of tourists.

One of the advantages the Kuyavian-Pomeranian voivodeship exhibits is the constantly upgraded network of thematic trails and bicycle/hiking routes. This type of tourist attractions has not only increased the region's competitiveness, but most of all elevated the general awareness of environmental protection, the region's history and the local community's life. 
Table 5 presents the number of different routes in the Kuyavian-Pomeranian voivodship, in comparison with selected voivodships.

Hiking routes prevail in the Kuyavian-Pomeranian region. Compared to the other voivodships presented in Table 5, the Kuyavian-Pomeranian voivodeship has the largest number of such routes. In the Warmian-Masurian voivodship, on the other hand, bicycle routes prevail, similarly to the Łódź voivodship.

\section{Table 5.}

Number of tourist routes in the Kuyavian-Pomeranian voivodeship versus selected voivodeships

\begin{tabular}{|c|c|c|c|c|}
\hline \multirow{2}{*}{ No. } & Type of tourist & \multicolumn{3}{|c|}{ Voivodeship } \\
\cline { 3 - 5 } & route & Kuyavian-Pomeranian & Warmian-Masurian & Lódź \\
\hline 1. & Bicycle trails & 75 & 105 & 44 \\
\hline 2. & Hiking trails & 126 & 35 & 21 \\
\hline 3. & Thematic trails & 4 & 18 & 9 \\
\hline 4. & Canoeing routes & 15 & 18 & No data \\
\hline
\end{tabular}

Source: own elaboration based on: http://www.szlaki.mazury.pl/; https://kujawsko-pomorskie.travel/pl/ node/51395; https://wirtualneszlaki.pl/szlaki-piesze-lista; https://wirtualneszlaki.pl/szlaki-rowerowelista; https://szlaki.pttk.pl/index.html.

Apart from the tourist attractions, the voivodeships' competitiveness is also determined by the number of eateries. Figure 1 presents the number of eateries recorded in 2010, 2015, 2017 and 2019 in the Kuyavian-Pomeranian, the Warmian-Masurian and the Łódź voivodships.

The above-presented data indicates that the Kuyavian-Pomeranian voivodeship offers more eateries than the other voivodships under examination.

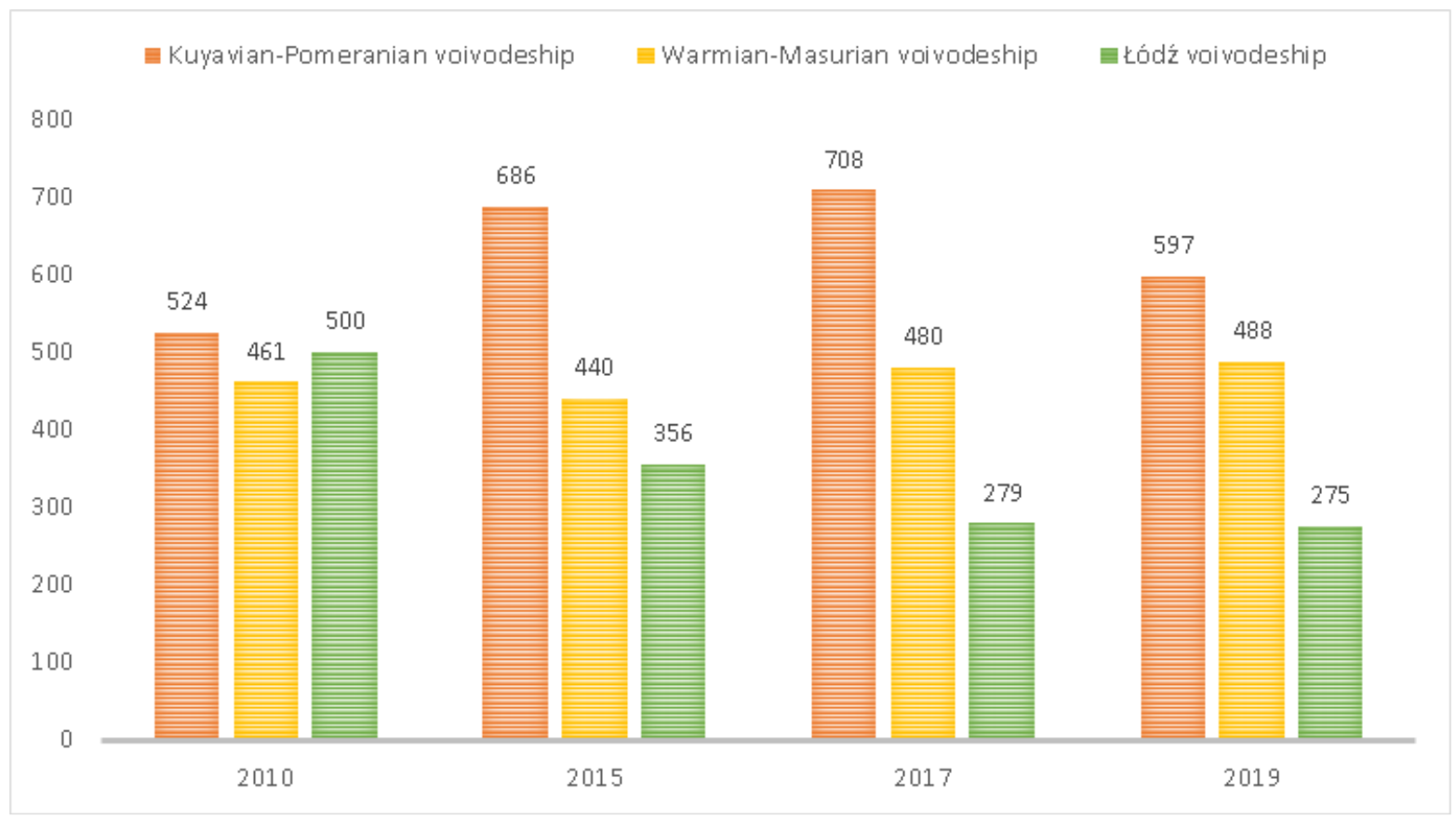

Figure 1. The number of eateries in the Kuyavian-Pomeranian voivodeship versus selected voivodeships in 2010, 2015, 2017, 2019. Adapted from: own elaboration based on: Rocznik Statystyczny Województwa Kujawsko-Pomorskiego 2019; Turystyka w województwie warmińskomazurskim w 2010, 2015, 2017, 2019 roku; Ruch turystyczny w Łodzi i województwie łódzkim w 2010, 2015, 2017, 2019 roku. 
The TeH2O Water, Industry and Craft Trail created in 2012 may have contributed to the increase in the tourist competitiveness of the Kuyavian-Pomeranian voivodeship as well. The trail covers 15 sites located in Bydgoszcz. The TeH2O Trail facilities include: the Exploseum, the Granaries on the Brda River, the Mill Island, the Bydgoszcz Canal, the Soap and History of Dirt Museum, the Water Tower, the Museum of Photography, the Bydgoszcz Beer Brewery, the 'Pod Łabędziem' Pharmacy, the Waterworks Museum, the Bookbindery, the former municipal gas plant, the Woodworking Machinery Factory, the 'Lemara' Barge, the Bydgoszcz Canal Museum (the Water, Industry and Craft Trail in Bydgoszcz).

The trail's designation and development was one of the reasons for the increase in the flow of the tourists to the city of Bydgoszcz. Figure 2 presents the number of tourists visiting Bydgoszcz. It shows how the number of tourists increased each year. Due to the fact that the $\mathrm{TeH} 2 \mathrm{O}$ thematic trail encompasses most commonly visited facilities, it can safely be stated that its existence has increased the tourist competitiveness of the city of Bydgoszcz.

The TeH2O Water, Industry and Craft Trail in Bydgoszcz has not only added to the tourist competitiveness of the Kuyavian-Pomeranian voivodeship, but also improved the city's attractiveness through the provision of a completely new offer. The trail combines history, technology and the care for the natural environment, which fits in the canons of sustainable tourism. Additionally, it has been a tourist attraction not only for those visiting Bydgoszcz, but for its residents as well. According to the information provided by Mrs. Kinga Puchowska, the $\mathrm{TeH} 2 \mathrm{O}$ Water, Industry and Craft Route Coordinator, each year the trail is visited by 100 to 150 thousand people. The exact number of the people visiting the trail is quite difficult to be estimated, since a large number of tourists prefer recreation on the Mill Island or the Bydgoszcz Canal, which are part of the trail structure.

In 2006, the Wietrzychowice Cultural Park was established based on the Resolution of the Izbica Kujawska Commune Council. This park is located in the area of the Koło Forest District, encompassing 6 megalithic tombs estimated to be 5500 years old. The park's advertising campaign was based on the following slogan: 'Tombs older than Stonehange or the pyramids in Egypt'. It is worth mentioning that after the infrastructure around the tombs had modernized and reconstructed, they were included in the Wietrzychowice Culture Park on the European Route of Megaliths.

Existence of the Culture Park has not only contributed to the increase in the tourist competitiveness of both the region and the town of Wietrzychowice, but also helped bring tourists back to other local towns. As part of the European Heritage Days, a festival called 'Time Machine' is organized annually in September. It helps promote the park and present some of the oldest and most valuable monuments in Europe. Local sellers can also present their products and services.

Surely one of the most recognizable places in the Kuyavian-Pomeranian voivodeship is the city of Torun, advertised as 'The City of Nicolaus Copernicus', the 'Gingerbread City', the 'Touchable Gothic'. The most famous place in Torun is the Old Town, which is on the 
UNESCO World Heritage List. The places most visited in Torun include: the Town Hall tower, the Planetarium, the ruins of the Teutonic Castle, the Copernicus House, the Gingerbread Museum, etc.

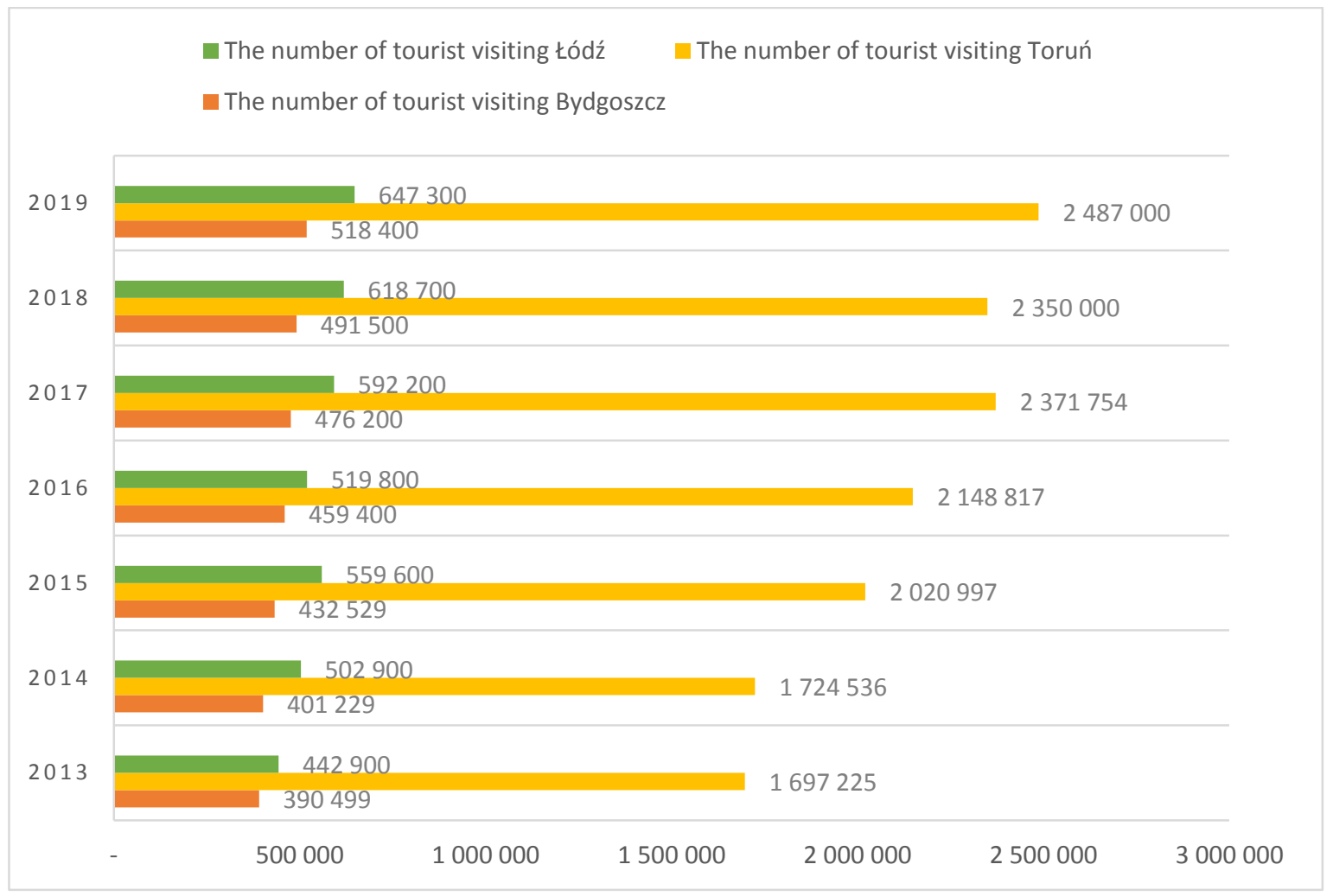

Figure 2. The number of tourist visiting Bydgoszcz, Torun and Łódź in the years 2013-2019. Adapted from: own elaboration based on: Badanie ruchu turystycznego w Bydgoszczy w latach 2013-2019; Monitoring ruchu turystycznego w latach 2013-2019; Turystyka w województwie łódzkim w latach 2013-2019.

Figure 2 shows the number of tourists visiting the cities of Torun, Bydgoszcz and Łódź. The above-presented data indicates that each year more tourists decided to visit the cities examined. It can be seen that Torun is one of the most visited places in the KuyavianPomeranian voivodeship, which results not only from the fact that the monuments are perfectly preserved, but primarily from the care for the history of the place and the respect for the local community's functioning.

\section{Conclusion}

The study attempted to define sustainable development and sustainable tourism. One of the most important documents on sustainable tourism, Agenda 21, has been discussed.

Based on the areas selected by the Author, where management is carried out in accordance with the principles of sustainable tourism, the influx of tourists in the Kuyavian-Pomeranian voivodeship has been analyzed. This allowed achievement of the objective assumed. 
In the period under analysis, an increase can be observed in the number of the tourists visiting the two largest cities of the Kuyavian-Pomeranian voivodeship, i.e. Bydgoszcz and Torun. The number of eateries operating in the Kuyavian-Pomeranian voivodeship increased each year, compared to the other two voivodships under examination. This has had significant impact on the voivodeship's increased tourist competitiveness. The Kuyavian-Pomeranian voivodeship additionally offers a large number of tourist routes.

The facilities or areas discussed not only contribute to increasing influx of tourists, but above all promotes development of new places, which are visited by travellers. As a result, the tourist competitiveness of the Kuyavian-Pomeranian voivodeship has increased.

Based on the analysis carried out, several conclusions can be drawn:

1. Owing to the increase in the inflow of tourists, both domestic and foreign, the sustainable tourism facilities discussed, such as the TeH2O Trail, the Wietrzychowice Cultural Park and the city of Torun, can within a few years become important destinations for domestic, and perhaps also European, tourists.

2. It should be noted that sustainable tourism is not just another form of tourism, but a specific manner of tourism management. One of its main objectives is to create conditions under which coherence between the natural resources of a protected area and the needs of its local population as well as the needs of tourists and the tourism sector can be achieved.

3. The growing influx of tourists to the Kuyavian-Pomeranian voivodeship was an impulse to expand the accommodation and catering infrastructure.

4. Sustainable tourism and the facilities operated in accordance with its principles helped raise people's awareness of ecology, environmental protection and respect for the local community.

One very positive aspect entails the fact that the development of tourist facilities in accordance with the principles of sustainable tourism brought tangible economic benefits. These benefits mainly could be visible in the profits obtained from the facilities located near the tourist attractions, i.e. hotels, restaurants, stores, and souvenir shops. Development of sustainable tourism facilities reinforces a given region's competitive position by strengthening the cultural, social, economic and spatial ties. It can therefore be concluded that raised awareness of the care for the natural environment has been a stimulus for the local community and tourist activity, which contributes to the increase in the tourist competitiveness of the Kujawsko-Pomorskie voivodeship. 


\section{References}

1. Agenda 21 for the Travel and Tourism Industry. Available online https://www.e-unwto.org/ doi/book/10.18111/9789284403714, 18.11.2020.

2. Badania ruchu turystycznego w Bydgoszczy $w$ latach 2012-2019. Available online https://visitbydgoszcz.pl/pl/badania, 19.11.2020.

3. Bajdor, P., Grabara, J., (2012). Turystyka zrównoważona - przegląd literatury i charakterystyka. In: S. Nowak (ed.), Katowice: Akademia Wychowania Fizycznego im. J. Kukuczki.

4. Burchard-Dziubińska, M. (2014). Idea zrównoważonego rozwoju. In: Zrównoważony rozwój - naturalny wybór. Łódź: Wydawnictwo Uniwersytetu Łódzkiego.

5. Ferreira, A. (2017). Between Development and Sustainability: Symbiotic Synergy or Irreconcilable Duality. Central European Review of Economics and Management, Vol. 1, No. 2.

6. Gawor, L. (2006). Idea zrównoważonego rozwoju jako projekt nowej ogólnoludzkiej cywilizacji. Diametros, No. 9.

7. Główny Urząd Statystyczny. Available online http://demografia.stat.gov.pl/ bazademografia/Tables.aspx, 18.11.2020.

8. Główny Urząd Statystyczny. Available online https://lodz.stat.gov.pl/dane-owojewodztwie/, 29.11.2020 .

9. Główny Urząd Statystyczny. Available online https://olsztyn.stat.gov.pl/, 29.11.2020.

10. Karbowiak, K. (2008). Turystyka w województwie warmińsko-mazurskim - stan obecny i perspektywy rozwoju. Roczniki Nauk Rolniczych, Seria G, T. 95, Z. 3-4.

11. Kassenberg, A. (2007). Zrównoważony rozwój a koncepcja przestrzennego zagospodarowania kraju. In: G. Gorzelak, A. Tucholska (eds.), Rozwój, region, przestrzeń. Warsaw: MRR, EUROREG.

12. Komorowski, J., Hołderna-Mielcarek, B. (2019). Economic and Social Consequences of Mass Tourism in City Management - the Case of Poznań and Wrocław. Studia Periegetica, No. 3(27), DOI: 10.26349/st.per.0027.02.

13. Kozłowski, S. (1998). Ekologiczne problemy przyszłości świata i Polski. Warsaw: Komitet Prognoz „Polska w XXI wieku” przy Prezydium PAN.

14. Lemkowska, M. (2020). Funkcje ubezpieczeń gospodarczych a zrównoważony rozwój. Wiadomości Ubezpieczeniowe, No. 2, https://doi.org/10.33995/wu2020.2.33.

15. Meadows, D.H., Meadows, D.L., Randers, J., Behrens, III W.W. (1972). The Limits to Growth. New York: Universe Book.

16. Monitoringu ruchu turystycznego $w$ Toruniu $w$ latach 2012-2019. Available online https://visittorun.com/pl/page/monitoring-ruchu-turystycznego, 19.11.2020. 
17. Niezgoda, A. (2004). Problems of Implementing Sustainable Tourism in Poland. The Poznań University of Economics Review, Vol. 4(1).

18. Our Common Future. Report of the World Commission on Environment and Development. Available online https://sustainabledevelopment.un.org/content/documents/5987ourcommon-future.pdf, 20.11.2020.

19. Płachciak, A. (2011). Geneza idei rozwoju zrównoważonego. Prace Naukowe Uniwersytetu Ekonomicznego we Wrocławiu. Ekonomia, No. 17(214).

20. Przewodnik - Turystyka, 2020, https://kujawsko-pomorskie.travel/pl, 18.11.2020.

21. Rocznik Statystyczny Województwa Kujawsko-Pomorskiego 2019, Available online https://bydgoszcz.stat.gov.pl/publikacje-i-foldery/roczniki-statystyczne/rocznikstatystyczny-wojewodztwa-kujawsko-pomorskiego-2019,4,12.html, 19.11.2020.

22. Rokicka, E., Woźniak, W. (2016). W kierunku zrównoważonego rozwoju. Koncepcje, interpretacje, konteksty. Łódź: Katedra Socjologii Ogólnej. Wydział EkonomicznoSocjologiczny. Uniwersytet Łódzki.

23. Runowski, H. (2002). Rozwój zrównoważony rolnictwa i gospodarstw rolniczych. Wieś i rolnictwo - perspektywy rozwoju. Warszawa: IERiGŻ, IRWiR PAN, SGH.

24. Rydz-Żbikowska, A. (2012). Geneza koncepcji zrównoważonego rozwoju oraz proces jej kształtowania się poprzez zawieranie globalnych porozumien. Gospodarka w Praktyce i Teorii, No. 1(30).

25. Sprawozdanie z działalności OT "Szlak Piastowski" za 2019 rok. Available online http://www.szlakpiastowski.com.pl/images/Pobierz\%20sprawozdanie\%20z\%20dzia\%C5 \%82alno\%C5\%9Bci\%20OT\%20Szlak\%20Piastowski\%20za\%20rok\%202019.pdf, 19.11.2020.

26. Stanny, M., Czarnecki, A. (2011). Zrównoważony rozwój obszarów wiejskich Zielonych Ptuc Polski. Próba analizy empirycznej. Warszawa: Instytut Rozwoju Wsi i Rolnictwa Polskiej Akademii Nauk.

27. Szlak Wody, Przemystu i Rzemiosła w Bydgoszczy, Idea Szlaku (2019). Available online https://ludzieitechnika.pl/artykul/24/idea-szlaku, 18.11.2020.

28. Szlaki kajakowe. Available online https://kujawsko-pomorskie.travel/pl/node/51395, 29.11.2020.

29. Szlaki Mazury. Available online http://www.szlaki.mazury.pl/, 29.11.2020.

30. Szlaki Piesze. Available online https://wirtualneszlaki.pl/szlaki-piesze-lista, 29.11.2020.

31. Szlaki Rowerowe. Available online https://wirtualneszlaki.pl/szlaki-rowerowe-lista, 29.11.2020.

32. Szlaki turystyczne w Polsce. Available online https://szlaki.pttk.pl/index.html, 29.11.2020.

33. Sztumski, W. (2006). Idea zrównoważonego rozwoju a możliwości jej urzeczywistnienia. Problemy Ekorozwoju, Vol. 1, No. 2. 
34. Tanguay, G.A., Rajaonson, J., Therrien, M.Ch. (2013). Sustainable Tourism Indicators: Selection Criteria for Policy Implementation and Scientific Recognition. Journal of Sustainable Tourism, Vol. 21(6).

35. The Act of April 27, 2001, Environmental Protection Law, Journal Of Laws 2018, item 799, as amended.

36. Turner, R.K. (1988). Pluralism in an environmental economics: a survey of the sustainable economic development debate. Journal of Agricultural Economics, Vol. 39.

37. Turystyka w województwie tódzkim w latach 2013-2019. Available online https://lodz.stat.gov.pl/opracowania-biezace/opracowania-sygnalne/sport-turystyka/, 29.11.2020.

38. Turystyka $w$ województwie warmińsko-mazurskim $w$ latach 2013-2019. Available online https://olsztyn.stat.gov.pl/opracowania-biezace/opracowania-sygnalne/sport-turystyka/, 29.11.2020.

39. Widawska-Stanisz, A., Majewska, B. (2019). Turystyka zrównoważona jako czynnik rozwoju lokalnego rynku pracy. Przedsiębiorczość i Zarządzanie, Vol. 20, Iss. 10.

40. WTTC, Oxford Economics, World Travel \& Tourism Council, Economic Impact Report. Available online https://wttc.org/Research/Economic-Impact, 18.11.2020.

41. Zawistowska, H, Dębski, M., Górska-Warsewicz, H. (2014). Polityka turystyczna. powstanie - rozwój - główne obszary. PWE. 